\title{
ÖZEL ORTAÖĞRETIM KURUMLARINDA PAYLAŞILAN LIDERLIK DAVRANIŞI VE ISTTEN AYRILMA NIYETI ARASINDAKI İLIŞKIDE PSIKOLOJIK RAHATLIK ALGISININ ARACI DEĞIŞKEN İLIŞKISI, KONYA ÖRNEĞI
}

Serdar YENER*

ÖZET

$\mathrm{Bu}$ çalışmanın amacı özel ortaöğretim kurumlarında paylaşılan liderlik davranışının işten ayrılma niyetine olan etkisinde psikolojik rahatlık algısının aracı değişken rolünü analiz etmektir. 2013-2014 eğitim döneminde Konya'da görev yapan 577 öğretmen ve yönetici araştırmanın evrenini ve bu evren içindeki 326 öğretmen ve yönetici örneklemini oluşturmaktadır. Olgular arasındaki ilişkiyi ölçmek için kullanılan Warppls sonuçları APC = 0.538, (P < 0.001), ARS = 0.628 $(\mathrm{P}<0.001), \mathrm{AARS}=0.627,(\mathrm{P}<0.001), \mathrm{AVIF}=1.971, \mathrm{AFVIF}=2.915, \mathrm{GoF}=0.623, \mathrm{SPR}=1.000, \mathrm{RSCR}=1.000, \mathrm{SSR}=$ $1.000, \mathrm{NLBCDR}=1.000$, değerleriyle uygun çıkmıştır. Bağımsız değişken olan paylaşılan liderliğin etkisi aracı değişkenin ilişkiye dahil edilmesiyle azalmış fakat anlamlılı̆̆ını yitirmemiştir $(\beta=-.74 ; p<.001$, aracı değişkenden önce $\beta=-0,84, p$ $<$.001). Dolayısıyla araştırmada psikolojik rahatlık algısının kısmi aracılık rolü gözlenmiştir.

Anahtar Kelimeler : Paylaşılan Liderlik, Psikolojik Rahatlık, İşten Ayrılma

JEL : D23, M12

Bu makale Özel Ortaöğretim kurumlarında Paylaşılan Liderlik Davranışı ve İșten Ayrılma Niyeti Arasındaki İlişkide Psikolojik Güvenlik Algısının Aracı Değişken İliş̧kisinin Araştırılması'” adlı doktora tezinden üretilmiştir.

Bu makale Katar'da 2015 yılında düzenlenen Conference on Education 2015 «Partners in Excellence» adlı uluslararası eğitim kongresinde ' 'How does psychological safety affect employee turnover'’ başlığıyla bildiri şeklinde sunulmuştur.

*Yrd.Doç.Dr., Sinop Üniversitesi İIBF, İşletme Bölümü, serdaryener@sinop.edu.tr 


\section{ABSTRACT}

The purpose of this research is to analyze the mediating role of psychological safety in the relation between distributed leadership and turnover intention in private Schools. 577 private school teachers and leaders who are working in 2013-2014 education term in Konya are composing universe and 326 of them composing sample. The results of Warppls which is used to measure the relation among phenomenons are suitable with values of AP $8,(\mathrm{P}<0.001), \mathrm{ARS}=0.628$ $(\mathrm{P}<0.001), \mathrm{AARS}=0.627,(\mathrm{P}<0.001), \mathrm{AVIF}=1.971, \mathrm{AFVIF}=2.915, \mathrm{GoF}=0.623, \mathrm{SPR}=1.000, \mathrm{RSCR}=1.000, \mathrm{SSR}=1.000$, $\mathrm{NLBCDR}=1.000$. The effect of independent variable distributed leadership decreased when mediating variable is added to regression but did not lose mean $(\beta=-.74 ; \mathrm{p}<.001$, before mediating variable $\beta=-0,84, \mathrm{p}<.001)$. Therefore partially mediating effect of psychological safety is observed in research.

Keyword: Distributed Leadership, Psychological Safety, Turnover Intention

JEL : D23, M12

\section{GİRİş}

Paylaşılan liderlik okul yöneticilerinin sorumluluk ve güçlerini yönetimin ve eğitimin çeşitli fonksiyonlarında bilgi, tecrübe sahibi çalışanlarıyla paylaşmasını ifade etmektedir (Spillane vd., 2004). İşten ayrılma niyeti işten ayrılma sürecinde son safha olup bu safhadan sonra işten ayrılma davranışı oluşmaktadır. Psikolojik rahatlık algısı organizayonlarda çalışanın herhangi bir konuda organizasyon için faydası olacağını düşündüğü fikrini ifade ederken, görüşlerini paylaşırken yenilikleri sunarken hissettiği psikolojik olarak kendini rahat hissetme seviyesini gösteren alanyazına yeni girmiş bir olgudur.

1250 yılında güney Arabistan'da Sina yarımadasındaki Midian bölgesinde din adamı olarak yaşayan Jethro'nun çobanı ve damadı olan Musa'nın Mısır'a gitmesi, Mısır' da İsrailoğullarının başına geçmesi, buradan İsrailoğullarının kutsal saydığı Kenan diyarını ele geçirmek için yola çıkmasının hikâyesinin İncil'deki (Exodus 18: 21 and 22) anlatımına göre Jethro damadı Musa'yı ikaz ederek "Tek başına yapmaya çalıştığın bu iş hiç iyi bir iş değil ve bu böyle devam ederse senin ve halkının zarar görmesine yol açacaktır, doğru olan ise halkının gücünü kullanarak ve kendi gücünle birleştirerek Kenan diyarına gitmektir'” şeklinde yönlendirmiştir (NCSL, 2004a).

Tarihsel çerçevede, paylaşılan liderliğin vuku bulduğu gelişmelere bakılırsa birçok örnekle karş1laş1labilir. İnsanoğlunun varoluşundan günümüze kadar çevresiyle ve birbiriyle olan savaşının her aşamasında paylaşılan liderlik örneği görülmüştür. Bu örnekler bireysel ölçekte, toplumsal ölçekte, ulusal ölçekte, dinsel ölçekte, evrensel ölçekte karşımıza çıkmıştır (Yener, 2015). İnsanoğlunun izlerinin gittiği 200.000 yıl öncesinden günümüze kadar insan davranışı üzerine yapılan araştırmalar incelendiğinde, göçebe tipi yaşam süren insanın, diğer insana karşı herhangi bir üstünlüğünün söz konusu olmadığı, artı ürün olgusunun ve hiyerarşik bir sosyal yapılanmanın bile olmadığı anaerkil klanlarda ortak sorumlulukların insanlar arasında paylaşılarak topyekün yaşam ve istikrarın sürdürülebildiği görülmektedir (Erden ve Sayılgan,2011)

Yüksek işgören devir oranı günümüz ekonomik koşullarında ayakta kalmaya çalışan örgütlerin geneline yakınını tehdit etmektedir. Rekabetin koşullarından biri olan kalitede farklılaşmak amacından uzaklaşma lüksü bulunmayan özel okulların bunun yanında maliyette farklılaşmak gibi bir seçeneği de bulunmamaktadır. Başarılı özel okulların kalitede ve maliyette farklılaşmak amaçlarını dengede tuttuğu görülmektedir. nada Akıl Sağlığı Komisyonu (MHCC)' nun oluşturmuş olduğu standartlar işverenlere çalışanları için psikolojik rahatlık ortamının oluşturulması için sistematik bir referans sunmaktadır. Kanada devletinde çalışanların \% 69'unun psikolojik rahatsızlıklara dayalı uzun dönemli rahatsızlıklarından dolayı iş alanlarındaki yokluğundan yıllık 51,8 milyar dolarlık bir kayba uğramaktadır. Bunun yanında hayali varlık ( Further Presenteeism, Fiziksel olarak çalışma alanında 
olup psikolojik olarak bulunmaması) olgusunun ekonomiye verdiği zarar ise bunun yaklaşık bir buçuk katıdır (Coldwell, 2012:17).

Alanyazı taramalarına göre paylaşılan liderlik davranışının oluşturduğu örgütsel iklimin işten ayrılma davranışını azaltması beklenmektedir. Bununla beraber paylaşılan liderlik olgusunu güçlendireceği düşünülen bazı psikolojik olguların psikolojik rahatlık algısı tarafindan sağlanmasıyla paylaşılan liderlik davranışının olduğu yerde psikolojik rahatlık algısının bu etkiyi düşüreceği yani paylaşılan liderlik davranışının etkisinin bir kısmını üzerine alarak aracı değişken bir rol üstlenebileceği düşünülmektedir.

\section{KURAMSAL ÇERÇEVE ve HIPOTEZLER}

\subsection{Paylaşılan Liderlik ve İşten Ayrılma Niyeti}

Geleneksel liderlik uygulamaları genelde kurumlarda yöneticilik pozisyonunu işgal eden lider rolündeki kişilerin makamının gücünü kullanmak ya da bu sınırlar içinde kendine has özelliklerle ilişkilendirildiği için (Fiedler, 1967;8) öğretim kurumlarındaki branşlarında ya da konularındaki ihtisaslaşmış kendi alanında lider rolünü oynayan öğretmenlerin liderlik uygulamalarını açıklamakta yetersiz kalmaktadır. Yapılan araştırmalar konumsal liderlik (Positional Leadership, yöneticilik) perspektifinden (Daft, 2005;5) bakılarak paylaşılan liderlerliğin anlaşılmasının güç olduğunu göstermektedir (Daft, 2005;12).

Geleneksel Bilişsel Teorinin ( Traditional Cognitive Theory) tersine Kurumsal Teoride ( Institutional Theory) karşılaşılan problemlerin aşılmasında içinde bulunulan kurumun imkan ve sınırlılıkları, kurumun zorlayıcılığı, kural ve gelenekler büyük rol oynamaktadır (Thelen, 2003:210). Paylaşılan liderlik alanyazında önerdikleriyle kurumsal teoriyle açıklanmaktadır (Spillane vd., 2004).

Günümüz değişken ve esnek çalışma ortamında yöneticilerin gözlem yapmadan faydalı bilgiye ulaşması imkânsızdır. Bu gözlem sayesinde okul içinde kendi alanlarında öne çıkmış ve paylaşılan liderlik rolünü yürüten diğer çalışanlara ulaşılabilir ve liderlik rolleri anlaşılabilir. Okulun sosyal ve kurumsal yapısını anlamadan, paylaşılan liderlik oluşturulamaz. Kendine güven, sosyallik, uyum, yardımlaşma gibi kişisel özellikler lideri diğerlerinin içinde öne çıkararak arkasında bir izleyenler gurubu oluşturur (Spillane vd.,2004).

Paylaşılan Liderlik, organizasyonlarda çalışanların konumları, ilgileri, eğilimleri, uzmanlıkları, yeteneklerine göre birtakım farklılıkları olduğu düşüncesiyle, çalışanların bu farklılıklarının yönetici tarafından algılanması, tespit edilmesi, çalışanların ve organizasyonun faydası için kullanılması yolunda birbirini tamamlaması veya paylaşılmasıdır. Bununla beraber bu farklılıkların anlaşılması ve yönetilmesi, gereken yer ve zamanda organizasyonun misyon ve vizyonu doğrultusunda kullanılması, kullanılma sürecinde diğer organizasyon çalışanlanının desteğinin yönlendirilmesi, yöneticinin esas görevi olmaktadır. Dolayısıyla paylaşılan liderlik, organizasyon sürecinde farklı rehber ve yönlerin, farklı yeteneklerle birleşerek sürece gitmesini sağlamayı ifade etmektedir (Serrat,2009).

İşgören devri, çalışma hayatının her alanında standartlar oluşturmaya çalışan ülkemizde hemen hemen her sektörde bir sorun olarak karşımıza çıkmaktadır. Makro düzeyde ülke ekonomisinde vasıflı işgören ihtiyacının artmasının yanında, işgören devir oranının yüksek olması da öncelikle işverene daha sonra da devlete finansal bir yük oluşturmaktadır.

Bothma ve Roodt (2012), işten ayrılma niyeti ölçeğinin geçerlilik ve güvenilirlik çalışmasında, işten ayrılmanın işgörenin işten ayrılma planının son safhası olduğunu, bundan sonra işten ayrılma davranışının geldiğini belirtmektedirler. İşten ayrılma niyeti ise işgörenin bilerek ve gönüllü olarak işten ayrılmayı istemesi olarak tanımlanmıştır (Abassi ve Hollman, 2000). İşten ayrılma niyeti ve gerçekten işten ayrılma arasında olumlu ve yüksek bir ilişkinin olduğu iddia edilmektedir. Yani işten ayrılma niyeti birçok araştırmacı tarafından işten ayrılma davranışının doğru bir göstergesi olarak 
alanyazına sokulmuştur (Podsakoff vd., 2007). İşten ayrılma, işgörenin hali hazırdaki çalışma ortamından bir kaçma yolu, veya işgörenlerin diğer işletmelerde çalışma isteği veya transferiyle yatay yönde bir hareket (horizontal mobility) olarak görülmektedir (Reily, 2006). Perez (2008), alanyazında işten ayrılma davranışının temel göstergesi olarak işten ayrılma niyeti olduğunun sıkça vurgulandığını belirtmektedir. Ancak bunun yanında, işten ayrılma niyeti olmadan da işten ayrılma davranışı gösteren çalışanların olduğunu ileri sürmekte ve ani çıkan durumlara karşı tepki olarak bu davranışı geliştirdiklerini iddia etmektedir. Fakat bu değerin toplam çalışanlarda \% 5 gibi bir oran oluşturduğunu gözlemlemiştir.

İşten ayrılma niyetinin paylaşılan liderlik davranışıyla ilişkisi Bireyin/çalışanın organizasyona bağlılık kapsamında değerlendirilebilir. Çalışanda böyle bir bağlılık algısı oluşturmak isteyen bir işveren, geçmişte sahip olunan maddi odaklı davranışların aksine, psikolojik odaklı davranışların da çalışanın işten ayrılma kararında etkili olduğunu gözönüne almalıdır. Bu bağlamda paylaşılan liderlik davranışı gösteren okul yöneticisinin çalışanların bilgi, tecrübe ve yeteneğini uygun şekilde onların kendi alanlarında liderlik rolünü üstlenmelerine imkân sağlayabilmektedir (Spillane, 2004). Diğer yandan onların motivasyon, performans ve bağl1lığını sağlayarak işten ayrılma niyetini azaltabileceği de bu bağlamda düşünülebilir. Yazında yapılan en bilindik çalışmada Meyer ve Allen örgütsel bağlılığı (Organizational Commitment, OC) psikolojik odaklı olarak duygusal, normatif, devam bağlılığı başlıkları altında incelemiş ve ölçeklendirmiş̧tir. Duygusal bağlılık boyutunda çalışanın örgüte karş1 duymuş olduğu duygusal bağl1lık vurgulanmış, çalışanların istekleri sonucu örgütte kaldıkları öne çıkarılmıştır. Örgütün çalışan için anlamının büyük olduğu ve çalışanların kendilerini örgütün bir parçası olarak gördüğü duygusal bağlılık tanımı, birçok araştırmada vurgulanmıştır (Ramsay ve Finney, 2006). Devam bağlılığında ise çalışanın organizasyondaki geçmişine bakarak sarf etmiş olduğu emek, gayret, zaman, fedakârlık sonucu elde ettiği kazanımların ( mevki, konum, makam ), ayrılması durumunda elinden gidebileceği düşüncesiyle işine devam etmesidir. Son olarak normatif bağlılık, çalışanın ahlak yargısından yola çıarak işe devam etmenin çalışan için en doğru ve ahlaki davranış olduğuna vurgu yapmaktadır. Burada toplumsal değer yargıları gereği çalışanın çalışmış olduğu örgüte karşı bir sorumluluk hissetmesi, bu sorumluluğunu da orada çalışarak yerine getirmesi normatif bağlılık gereğidir. Paylaşılan liderlik olgusunun çalışanların yetenek, tecrübe ve bilgilerine istinaden inisiyatif kurmasını teşvik eden güven olgusuyla çalışanların duygusal, devam ve normatif bağl1lığının oluşacağı ve sonuçta işten ayrılma niyetinin azalacağı önerilebilir.

İşten ayrılma niyetinin paylaşılan liderlik olgusuyla olan ilişkisinin dayandırılabileceği bir diğer kuram Lider-Üye etkileşim kuramıdır. Lider-Üye Etkileşim Kuramı liderin herbir üyeye özel bir ilişki formu geliştirdiğini önermektedir (Dunegan vd. 2002). Bu sayede çalışanın örgüte olan bağının arttığ1 çeşitli çalışmalarda ortaya konmuştur (Deluga, 1994). Paylaşılan liderlik olgusuyla liderlerin örgüt içindeki çalışanların tecrübe ve yeteneklerine göre boyutlarla liderlik rollerini üstlendiği düşünülürse bu yönden bakıldığında paylaşılan liderlik olgusunun örgütsel bağı arttırarak işten ayrılma davranışını düşüreceği düşünülebilir (Bauer vd., 2006).

Paylaşılan Liderlik ve İşten ayrılma niyeti arasında bir ilişki olabileceği yönündeki önerme Beşeri sermaye (Human Capital) kuramına da dayandırılabilir. Beşeri Sermaye kuramı Adam Smith'in görüşlerine istinaden ilk olarak nobel ödüllü ekonomi bilimci Gary Becker tarafindan 1964 yılında alanyazına kazandırılmıştır. Becker (1993), ülkelerin topyekün gelişmesi için beşeri sermayeye yatırım yaparak, ekonomik kaynaklarla beraber kullanmasının şart olduğunu iddia etmiştir. Bu konuda da eğitim ve öğretimin temel vazgeçilmez unusurlar olduğunu belirterek okullarda verilen eğitimin yanı sıra görev başı eğitiminin de işletme hayatına sokulması gerektiğini söylemiştir. Bu bağlamda paylaşılan liderlik örgüt üyelerinin kendilerini geliştirmesi için görevbaşı eğitimler veya fırsatlar 
oluşturulmasını önermektedir (Bolden, 2011). Yapılan çalışmalar işletmelerin verdiği özel eğitimlerle çalışanın beklentilerinin olumlu bir ilişki içinde olduğunu dolayısıyla beklentisi yüksek olan çalışanın işten ayrılma niyeti de yüksek yüksek olacaktır. İşletmeler beşeri sermayeye yatırım yaparken beşeri sermayeyi memnun edecek imkanlar da sağlamak zorunda kalacaktır. Beşeri sermayesini arttıran işgören buna uygun alternatif arayışında aradığını bulamadığında işten ayrılma niyeti azalacaktır (Becker,1993).

Paylaşılan Liderliğin işten ayrılma niyetini etkileyebileceğini düşündüren bir başka kuram olan Eşleştirme teorisi (Mortensen,1988), araştırma teorisinden etkilenerek kişinin kararlarını verirken yetenek ve kabiliyetlerine göre uygun yapılardaki işletmelerde iş arama düşüncesini belirtmektedir. Araştırma kuramından çıkmasının nedeni ise çalışanın böyle bir araştırma sürecine girdikten sonra alternatif oluşturduğunda yetenek ve kabiliyetlerini eşleşme konusunda hedef işletmedeki imkan ve kabiliyetler konusundaki bilgisizliği ve belirsizlik oranı işten ayrılma düşüncesini etkileyebilmektedir. Çalışanın iş dünyasındaki bilgi ve deneyimi onun geliriyle doğru orantılıdır. Dolayısıyla bilgi ve deneyimiyle iş dünyasındaki iş alternatifleri hakkındaki bilgi ihtiyacını karşılayacak ve belirsizliği azaltacak, bu sadece tatmininin yüksek olmasını sağlayacak karar verecektir. Bu bağlamda Paylaşılan Liderlik olgusunun lidere çalışanların yetenek ve kabiliyetlerinden verimli ve etkin bir şekilde yararlanma görevi vermesi onlara uygun işlerde istihdam etme durumunu ortaya çıkarmaktadır. Dolayısıyla eşleştirme kuramına göre yetenek ve kabiliyetlerine uygun işlerde çalıştığını düşünen çalışanda işten ayrılma niyetinin oluşmayacağı düşünülmektedir.

Yukarıda sunulan düşüncelere göre aşağıdaki hipotez oluşturulmuştur.

$\mathbf{H}_{\mathbf{1}}$ Paylaşılan Liderlik davranışı işten ayrılma niyetini olumsuz ve anlamlı şekilde etkilemektedir.

\subsection{Paylaşılan Liderlik - Psikolojik Rahatık Algısı}

Edmondson (2003:3) Psikolojik rahatlık algısını, bireylerin çalışma alanlarında algıladıkları kişilerarası endişe olarak tanımlamaktadır. Bireyin herhangi bir konuda fikrini söylemesi, soru sorması, geri besleme yapması, hataları gündeme getirmesi, yeni bir fikir öne sürmesi şeklindeki çıkışlarında, diğer çalışanların tepkileri organizasyonda psikolojik rahatlık algısının çerçevesini çizmekte ve olumlu yada olumsuz psikolojik rahatlık algısının oluşmasını sağlamaktadır (Yener, 2015).

Samra ve diğerleri (2012:2), psikolojik rahatlık algısını tanımlarken psikolojik sağlık olgusuna atıfta bulunarak psikolojik sağlığı ve sağlıklı çalışma alanlarını, çalışanın çalışma ortamında karşılaşacağı ihmal, dikkatsiz, veya bilinçli davranışlar sonucu psikolojik sağlığının bozulmasının engellenmesi yönünde oluşturulmuş çalışma alanları olarak tanımlamaktadır. Psikolojik sağlık ve psikolojik rahatlık algısının, Kanada gibi bazı ülkelerde (Samra vd, 2002) çalışma ortamlarında çalışanın lehine korunması aynı derecede önemli olarak belirtilmiş olsa da stratejik açıdan psikolojik rahatsızlığı engelleyen güvenliğin sağlanması ve sağlığın korunması yönünde alınması gereken tedbirler için bir zorunluluk olarak karşımıza çıkmaktadır.

Edmondson (2003:4), çalışmasında bir organizasyonda yada çalı̧̧ma alanında psikolojik rahatlık algısının olup olmadığını tespit etmek için açık uçlu "Bu organizasyonda çalışmak nasıl bir duygu" sorusunu sorarak yanıtlara göre psikolojik rahatlık algısının sınırlarını çizmektedir. Psikolojik rahatlık algısı stres olgusunun organizasyon içindeki etkisiyle ilgilidir. Stres bireyin dış dünyadan aldığı uyaranlara karşı kontrol dışı vermiş olduğu tepki olarak tanımlanmaktadır. Stresör bu tepkiye yol açan uyaranlardır. Stres diğer bir tanımla bireyin bulunmuş olduğu organizasyonda iş koşullarının onu etkilemesi sonucu vücudunda özel biyokimyasal salgıların oluşarak soz konusu koşullara uyum için düşünsel ve bedensel olarak harekete geçmesidir (Eren,1998:224). 
Tanımlardan da anlaşılacağı gibi psikolojik rahatlık algısının göstergesi çalışma alanlarındaki stresin varlığıdır. Stres kaynakları çevresel diyebileceğimiz gürültüye maruz kalma, yoğun iş baskısı, zaman baskısı, ağır ve tehlikeli iş şartları ve duygusa diyebileceğimiz çevresel şartların sonucunda oluşan korku, öfke, hayal kırıklığı, mutsuzluk, tükenmişlik olabilmektedir. Stres fizyolojik alandada kendini hissettirmektedir. Strese maruz kalan birey alarm durumu (fizyolojik olarak etkilerin görüldüğü kalp atışlarının hızlanması, gözebeklerinin büyümesi, hipofiz bezlerinin salg1 salgılaması), Karşı koyma aşaması, ve karşı koymanın başarısız olması durumunda tükenme aşaması, başarılı olma durumunda alarm durumunun etkilerinin ortadan kalkma aşamasını yaşamaktadır. Stres yaratan faktörler bireyin kendinden kaynaklanan, çevreden kaynaklanan, organizasyondan kaynaklanan faktörler olabilmektedir (Baltaş ve Baltaş, 1987:32). Bu çalışmada organizasyondan kaynaklanan stres faktörlerinin etkileri dikkate alınmıştır. Organizasyondan kaynaklanan stres faktörleri;

- İşin gerekleriyle kişinin yeteneklerinin uyuşmaması,

- İşin niteliği,

- Diğer faktörler adı verilen çalışma ortamının sosyal olmayışı, otokratik yönetim anlayışı, değerlendirmede objektif kriterlerin olmayışı, kayırmacılık, liyakatsizlik, iletişimin monolog (tek yönlü) olması, yetersiz çalışma koşulları, gelişme ve değişmelerde yetersizliklerin olması, kariyer beklentilerinin yerine getirilememesi, tatmine edici ücret sisteminin yokluğu, çalışanlar arasında gruplaşmanın yaygınlığı, birlik ve beraberlik duygusunun bulunmayışı vb. faktörler olarak sıralanabilir.

Schepers vd. (2007:3), psikolojik rahatlik olgusunu Maslow'un motivasyon teorisine dayandırarak insanoğlunun ihtiyaçlar hiyerarşisinde temel fizyolojik ihtiyaçlardan sonra güvenlik ihtiyacını duyduğunu belirtmektedir. Çalışanlar çalışma ortamlarında hedeflere ulaşmak için güven duydukları çevreler aramaktadırlar. Organizasyonda fiziksel ya da psikolojik rahatlık olgusunun önemine ilişkin son yıllarda çalışmalar yapılmaktadır.

Organizasyon çalışanlarının birçoğu öyle ya da böyle diğerleri tarafindan değerlendirilmektedir. Organizasyonda diğerlerinin varlı̆̆ı, çalışanın diğerleri nezdinde algısının değerlendirilmesi tehlikesini oluşturmakta buda çalışanların her gün karşılaştı̆̆ imaj ve izlenimini muhafaza etme çabasını oluşturmaktadır (Yener, 2014:65).

Paylaşılan liderlik olgusunun psikolojik rahatlık olgusuyla öğrenme boyutunda ilişkisi Bandura (1997)'nın sosyal öğrenme kuramına dayandırılabilir. Sosyal öğrenme kuramında önerilen örgütte model olma davranışı ancak paylaşılan liderlik davranışıyla model olabilecek bilgi, yetenek ve tecrübeye sahip çalışanın kendi alanında inisiyatif ve sorumluluk kullanarak liderlik davranışı yapmasıyla oluşabilmektedir. Paylaşılan liderlik bu bağlamda çalışanlara liderlik imkanı sunduğunda onlara olan güvenini de göstermekte ve güven göstermede model olarak diğer çalışanlara da önayak olmaktadır. Psikolojik rahatlık algısının yerleşmesi için güven olgusunun şart olduğu belirtilmişti (Edmondson, 2003). Aynı çalışmada güven olgusuyla yerleşen psikolojik rahatlık algısının öğrenme davranışıyla sonuçlanabileceği ifade edilmektedir. Eggers (2010:2), psikolojik rahatlık olgusunun yerleşmiş olduğu çalışma alanlarında, çalışanların öğrenmeyle sonuçlanan hesaplı risk aldıklarında ödüllendirildiğini söylemektedir. Çalışanların psikolojik olarak güven duydukları ortamlarda sürece katılım, genellikle daha fazla öğrenme ve olumlu değişmeyle sonuçlanmaktadır. Psikolojik rahatlık olgusu, çalışanların süreçte geri besleme ve yardım için talebinde yetersiz algılanma endişelerini de azaltmaktadır. Psikolojik rahatık olgusu, çalışma ortamında açık ve hassas ilişkiler gerektirdiği için liderler, izleyenler ve çalışanlar arasında güven olgusunu gerektirmektedir. Eğer bir çalışan açık ve hassas ise diğerleriyle etkileşimi, faydalı bilgi paylaşımı, geri besleme alma ve verme konusunda açık olma, geleceğe yönelik motive olma ve geçmişten ders çıkarma, sözleriyle yaptıkları arasında bir uyum olma gibi davranışlarıyla özdeşleşmektedir. Açıklık (Transparency) ayrıca çalışanın diğer 
çalışanla duygularını ve değerlerini paylaşmasıdır. Açık olarak algılanan bir lider, izleyenlerinin yüksek katılım gösterdikleri psikolojik rahatlık olgusunun yerleşmiş olduğu bir çevre oluşturmaktadır. Yüksek katılım gösteren çalışanlar daha fazla güç ve sorumluluk duygusu ortaya koymaktadırlar. Çalışanlar diğerlerine sonucunu bilmedikleri süreçlerde hassas olduklarında güven olgusu pekişir. Güven olgusu ise lider ve izleyenler arasında karşılıklıdır. Liderler, izleyenlerine ve işe karşı güven olgusunu yerleştirmek ve sürdürmek için çalışmalıdır. Psikolojik rahatlığı yaşayan çalışanların olduğu bir çalışma ortamında birbirine güven duyan liderlerin icraatları genellikle izleyenlerin niyet ve maksatlarını karşılamaktadır. Yüksek nitelikli lider-izleyen ilişkileri öğrenme ve hedeflere ulaşma beklentisini yükseltmektedir.

Yukarıda sunulan literatür taramasına göre paylaşılan liderlik olgusunun oluşturacağ 1 güvene dayalı ortamda psikolojik rahatlık algısının artacağı düşünülmektedir. Buna göre aşağıdaki hipotez oluşturulmuştur.

$\mathbf{H}_{2}$ Paylaşılan liderlik olgusu psikolojik rahatlık algısını olumlu ve anlamlı şekilde etkilemektedir.

\subsection{Psikolojik Rahatık Algısı - İşten Ayrılma Niyeti}

Psikolojik rahatlık algısının işten ayrılma niyetini olumsuz ve anlamlı şekilde etkileyebileceğine ilişkin Coetzee (2005), Sosyal değişim kuramıyla, işten ayrılma davranışının etkilerini, örgütsel bağlılık bağlamında incelemiştir.

Bootzin ve Loftus (1983:485) Thomas Holmes ve Richard Rahe'nin yapmış oldukları stres envanterine vurgu yaparak insan hayatında strese yol açan faktörleri araştırmaları sonucu 0-100 puan arasında puanlamışlar ve işten ayrılma faktörüne 50 puan, işin yeniden düzenlenmesi faktörüne 39 puan, değişik iş yapma faktörüne 36 puan, işte sorumluluk değişikliği faktörüne 29 puan, amirlerle ilgili sorunlara 23 puan, olarak belirlemişlerdir. Bu endekse kişisel ve ailevi faktörlerde eklenebilmektedir. Bütün bu endeks faktörlerinden kişinin maruz kaldığı durumların puanları toplandığında 300 puanı geçtiğinde kişinin psikolojik rahatsızlık yaşadığı varsayılmış, 150-299 puan arasında ise buna aday olduğu belirtilmiştir. Sırf işe ilişkin faktörlerin 187 puan olduğu düşünülürse işe ilişkin alınması gereken tedbirler ve uyulması gereken normların öneminin ne kadar büyük olduğu görülecektir.

Örgütte çalışanların yaşadığ 1 stres düşük iş memnuniyeti yoluyla düşük iş bağl1lığına yol açmakta bu ise yüksek işten ayrılma niyetini oluşturmaktadır (Podsakoff ve Lepine, 2007; Elangovan, 2001). Okullarda psikolojik rahatlık algısının işten ayrılma niyetini olumsuz olarak etkileyebileceği olgusu Hirscman (1970) kaçma-konuşma-sadakat kuramına dayandırılabilir. Çalışanların sahip olduğu bilgi, deneyim ve yeteneği kullanmasının fiziksel ve psikolojik yollarla engellendiği ortamlarda çalışanların işe olan bağlılığının azalarak işten ayrılma niyetinin oluşacağı ve işten ayrılacakları düşünülmektedir.

Psikolojik rahatlık algısının işten ayrılma niyetini etkilemesi Maslow'un ihtiyaçlar hiyerarşisine de dayandırılabilir. Kaya (2006:245) organizasyonda stresin kaynağını ise örgütsel çatışmaya bağlamaktadır. Örgütsel Çatışma çalışanların fizyolojik ve psikolojik ihtiyaçlarının tatminine engel olan sıkıntıların meydana getirdiği gerginlik yani psikolojik rahatlığın yaşanmadığı durumlarda psikolojik tatmin yaşanmayacak ve çalışanların bu tatmini yaşayacak yerlerin arayışına girecekleri önerilmektedir.

Psikolojik rahatlık algısının işten ayrılma niyetiyle olan ilişkisi sosyal mübadele kuramına da dayandırılabilir (Blau, 1964). Sosyal mübadele kuramı çalışanın örgütten psikolojik olarak ne algıladığını sorgulamaktadır. Buna göre örgüt topyekün tüm üyelerine karşı destekleyici, teşvik edici, hoşgörülü davranış gösterdiğinde çalışanlarında örgütte çalıştıkları sürece psikolojik rahatlık algılarının yüksek olacağı önerilmektedir (Yener, 2015). Sosyal değişim teorisi, kişilerarası 
etkileşimin ödül beklentisini yükseltirken kayıpları azaltma niyetiyle yönlendiğini ifade etmektedir. Çalışanların örgütten aldıkları pozitif desteğe daha fazla ve içten çalışarak karşı1ık verecekleri düşüncesi sosyal değişim kuramının temelidir. Bu da çalışanların kendilerini örgütün bir parçası olarak görmeleri sonucu oluşmaktadır. Coetzee (2005), çalışanların sosyal değişim teorisine göre örgütsel bağl11ıkları yüksekse işten ayrılma davranışının düşeceğini iddia etmektedir.

Örgütsel denge kuramı (Organizational Equilibrium Theory) Henry Fayol'dan beri sorgulanmaktadır. Gazendam ve Simons (1998), örgütsel denge kuramında çalışanın beklenti ve ihtiyaçlarıyla organizasyona verdiği katkının dengelenmesi gerektiğini iddia etmektedir. Bunun yanında işverenin de organizasyon ihtiyacıyla çalışandan aldığı katkıyı dengelemesi gerekmektedir. Eğer çalışanın organizasyona yaptığı katkıyla organizasyondan aldığı tatmin düzeyi dengesiz olursa işi bırakacaktır. Bu bağlamda çalışan örgüte verdiği performansla aldığı güven olgusunu, psikolojik olarak rahatlama olgusunu dengeleyemezse çalışanda işten ayrılma niyetinin oluşacağ düşünülmektedir. Benzer durumda yapılan bir çalışmada Mano (1994), örgütsel denge kuramı konusunda yapmış olduğu karşılaştırma çalışmasında dengesizlik algılayan çalışanın işi bırakacağını iddia etmektedir. Alanyazı taramasına göre aşağıdaki hipotez oluşturulmuştur.

$\mathbf{H}_{3}$ Olumlu psikolojik rahatlık algısı işten ayrılma niyetini olumsuz ve anlamlı şekilde etkilemektedir.

\subsection{Psikolojik Rahatlık Algısının Aracı Rolü}

Sosyal bilimler araştırmalarında aracılık rolü iki değişken arasındaki ilişkinin etkisini üzerine alabilen üçüncü değiş̧en olabileceği üzerinedir. Buna göre aracı değişkenin kullanılmadığı bağımsız ve bağımlı değişken ilişkisinde olacak etki aracı değişken analize tabi tutulduğunda düşmesi beklenir. Çünkü aracı değişken bağımsız değişkenin bağımlı değişken üzerinde oluşturduğu etkinin bir kısmını üzerine alarak bağımsız değişkenin etkisini azaltacaktır. Bir değişkenin aracı değişken rolünü üstlenebilmesi için bir takım yeterliliklerin olması gerekmektedir. Bunlar ;

- Bağımsız değişken bağımlı değişkeni anlamlı bir şekilde etkilemelidir.

- Bağımsız değişken aracı değişkeni anlamlı şekilde etkilemelidir.

- Aracı değişkeni bağımlı değişkeni anlamlı şekilde etkilemelidir.

- Bağımsız değişkenin bağımlı değişken üzerindeki etkisi aracı değişkenle birlikte analiz edildiğinde düşmelidir. Bu düşüş anlamlı oluyorsa tam aracılık etkisinden, anlamsız oluyorsa kısmi aracilık etkisinden bahsedilir.

Paylaşılan liderlik davranışının alanyazında bahsedilen tanımı incelendiğinde birtakım olgularının psikolojik rahatık algısının oluşması için gerekli ortamı sağladığı görülmektedir (Yener, 2015). Paylaşılan liderlik davranışının anlamlı bir şekilde görüldüğü bir örgütte çalışanların kendilerine değer verildiği ve güvenildiği algısının da oluşacağı düşünülmektedir. Bunun yanında psikolojik rahatlık algısının önermiş olduğu alt olgularla paylaşılan liderlik davranışının organizasyonda oluşturacağ 1 etkileri oluşturabileceği düşünülmektedir. Buna göre araştırma modelimizde paylaşılan liderlik davranışının işten ayrılma niyetine olan etkisinde psikolojik rahatlık algısının aracı değişken role sahip olabileceği önerilmektedir. Buna göre aşağıdaki hipotez oluşturulmuştur.

$\mathbf{H}_{\mathbf{4}}$ Psikolojik rahatlık algısı paylaşılan liderlik davranışı ve işten ayrılma niyeti arasında aracı role sahiptir. 


\section{YÖNTEM}

Araştırmada veriler anket yöntemi kullanılarak toplanmıştır. Toplanan veriler SPSS 21'de analiz edilerek tanımlayıcı istatistik bilgileri elde edilmiştir. Veriler arasındaki ilişki için Kısmi En Küçük Kareler Yönteminin kullanıldığı WarpPLS 4.0 uygulaması kullanılmıştır. Program özellikle örtük değişkenlerin modeldeki etkilerinin ortaya koyulmasında güvenilir sonuçlar veren güncel bir uygulamadır. Kock (2013) WarpPLS uygulamasının yapısal eşitlik modelleme analizi yapan programlar içinde doğrusal olmayan fonksiyonlar içindeki örtülü değişkenleri açığa çıkararak kurulan ilişkide çoklu değişkenlerin katsayılarını hesapladığını belirtmektedir.

\subsection{Evren ve Örneklem}

Araştırma evrenini Konya il sınırları içinde bulunan özel ortaöğretim kurumları oluşturmaktadır. 2013-2014 öğretim yılında faaliyet gösteren 27 özel öğretim kurumu olup bu kurumlarda toplam 577 öğretmen görev yapmaktadır. Bu öğretmenlerin 300 tanesi kadın, 277 tanesi erkektir. 346 öğretmenin sosyal branştan öğretmen, 231 öğretmenin sayısal branşlı öğretmen olduğu istatistiklerde sabittir. Bu çalışmada Konya İl Milli Eğitim Müdürlüğünün 2013-2014 yı1ı örgün eğitim istatistikleri esas alınmıştır. Bu okulların içinde seçim yapılırken evreni temsil etmesi bakımından öğretmen mevcutları dikkate alınmış buna istinaden uygun olan 7 okul belirlenmiş bu okullara gönderilen 350 anketin 336 tanesi geri dönmüş, geri dönen anketlerden 10 tanesinde geçersiz sayılacak şekilde işaretleme hatası olması sebebiyle geçerli anket sayısı 326 taneye düşmüştür.

\subsection{Veri Toplama Araçları}

Veri toplama araçları olarak Türkçe geçerlik ve güvenirliği Özer ve Beycioğlu (2013) tarafından yapılmış 10 maddelik 5'li Likert tipi paylaşılan liderlik davranışları adlı ölçek kullanılmıştır. Psikolojik rahatlık algısı ölçeği olarak Edmondson (1999) ölçeği kullanılmış olup ölçekteki sorular branşı yabancı dil olan öğretim görevlileri tarafından Türkçe'ye çevrilmiş, daha sonra farklı uzmanlar tarafından İngilizce'ye geri çevrilerek kullanılmıştır. Orjinal ölçeğin Cronbach Alpha güvenirlik katsayısı 0,62 çıkmasına rağmen ifadeler Türkçe anlaşılabilirliğini arttırmak için pilot uygulamadan sonra açılarak tekrar uygulanması sonucunda 0,758 bulunmuştur. Araştırmada kullanılan psikolojik rahatlık olgusu Yener (2015a) tarafindan doktora tezinde psikolojik güvenlik olgusu olarak kullanılmıştır. Daha sonra Yener (2015b) tarafından Psikolojik rahatlık ölçeğinin geçerlik ve güvenirlik çalışmasında yapılan pilot uygulamalarda sosyokültürel olarak güvenlik kelimesi ile anlatılmak istenen olgunun anlatılamayacağı belirtilerek Türkçe geçerlik ve güvenirlik çalışmasında psikolojik rahatlık olgusu olarak kullanılmıştır. Dolayısıyla bu çalışmada da olgu doktora tezindeki orjinal çalışmasından farklı olarak psikolojik rahatlık olarak kullanılmıştır. İşten Ayrılma Niyeti Şenyüz (2003)'ün 3 maddelik geçerlilik ve güvenilirlik çalışması yapılmış işten ayrılma niyeti ölçeği ile ölçülmüştür.

\subsection{Güvenirlik Çalışması}

Ölçeklere ilişkin güvenirlik sonuçları aşağıda olup analiz için yeterli güvenirliği sağladıkları görülmüştür. 


\section{Tablo 3.1 Değişkenlerin Güvenirlik Analiz sonuçları}

\begin{tabular}{|l|l|l|l|}
\hline Araştırma Ölç. & Composite Rel. Coef. & Cronbach's Alpha Coef. & Average Variance Ext. \\
\hline Paylaşı1lan Lid. & 0,912 & 0,892 & 0,512 \\
\hline Psikolojik Güv. & 0,823 & 0,758 & 0,417 \\
\hline İşten Ayrılma Ni. & 0,973 & 0,958 & 0,924 \\
\hline
\end{tabular}

\subsection{Geçerlik Çalışması}

Değişkenler arasındaki ilişkiye dair daha önce saptanan bir hipotezin test edilmesi amacına yönelik geçerlik analizi yapılır (Özçelik,1981). Kock (2013) Faktör analiz sonuçlarına bakıldığında ölçek alt faktörlerinin ölçekle kesiştiği değerler okunduğunda bu combined loadings değerini yani araştırmanın yapısal geçerliliği konusunda referans olacak değeri verdiğini belirtmektedir. Bu analizde görülecek iki değer bunlar P değerlerinin anlamlı olması ve Combined Loading değerinin 0,3 değerine eşit ya da yüksek çıkması yapısal geçerliliğin sağlandığını göstermektedir (Tinsley ve Tinsley 1987, Draper ve Diğerleri,2003). Bir değişkenin 0.3'lük faktör yükü, faktör tarafindan açıklanan varyansın \%9 olduğunu gösterir. İşaretine bakılmaksızın 0.6 ve üstü yük değeri yüksek, 0.3-0.59 arası yük değeri orta düzeyde büyüklükler anlamına gelir ve bu değerle değişken çıkartmada önem taşır (Eroğlu,2003). Aşağıdaki veriler incelendiğinde önerilen eşik değerlerin üzerinde sağlandığı görülmektedir. 
Faktör Analizi Sonuçları

\begin{tabular}{|llllll|}
\hline & \multicolumn{7}{c|}{ Combined loadings and cross-loadings * } \\
\hline & Liderli & İsAyNiy & PsiGuv Type & SH & P değeri \\
\hline PayLide & 0.675 & 0.152 & 0.425 & 0.048 & $<0.001$ \\
\hline PayLide & 0.798 & -0.145 & -0.154 & 0.048 & $<0.001$ \\
\hline PayLide & 0.772 & -0.253 & -0.079 & 0.048 & $<0.001$ \\
\hline PayLide & 0.645 & 0.038 & 0.800 & 0.048 & $<0.001$ \\
\hline PayLide & 0.587 & 0.082 & 0.282 & 0.048 & $<0.001$ \\
\hline PayLide & 0.614 & 0.211 & 0.009 & 0.048 & $<0.001$ \\
\hline PayLide & 0.792 & -0.106 & -0.233 & 0.048 & $<0.001$ \\
\hline PayLide & 0.798 & -0.236 & -0.297 & 0.048 & $<0.001$ \\
\hline PayLide & 0.712 & 0.239 & -0.234 & 0.048 & $<0.001$ \\
\hline PayLide & 0.728 & 0.150 & -0.279 & 0.048 & $<0.001$ \\
\hline IstenAy & 0.013 & 0.979 & -0.007 & 0.048 & $<0.001$ \\
\hline IstenAy & -0.031 & 0.976 & -0.021 & 0.048 & $<0.001$ \\
\hline IstenAy & 0.018 & 0.927 & 0.030 & 0.048 & $<0.001$ \\
\hline PsiGuv1 & -0.536 & -0.198 & 0.528 & 0.048 & $<0.001$ \\
\hline PsiGuv2 & 0.077 & 0.077 & 0.846 & 0.048 & $<0.001$ \\
\hline PsiGuv3 & -0.412 & -0.110 & 0.432 & 0.048 & $<0.001$ \\
\hline PsiGuv4 & 0.151 & 0.014 & 0.832 & 0.048 & $<0.001$ \\
\hline PsiGuv5 & -0.683 & -0.217 & 0.390 & 0.048 & $<0.001$ \\
\hline PsiGuv6 & 0.484 & 0.141 & 0.639 & 0.048 & $<0.001$ \\
\hline PsiGuv7 & 0.332 & 0.103 & 0.693 & 0.048 & $<0.001$ \\
\hline Sonuç & 0.075 & & \\
\hline
\end{tabular}

* Sonuçlar warpPLS analizi ile elde edilmiştir.

\subsection{Korelasyon Analizi}

İki değişken arasındaki ilişkinin derecesini ve yönünü belirlemek amacıyla kullanılan istatistik yöntemlerden olan korelasyon analizinde değişkenlerin bağımlı veya bağımsız olması dikkate alınmaz. Korelasyon katsayısı -1 ile +1 arasında değişen değerler alır $(-1 \leq \mathrm{r} \leq+1)$. . Katsay1, ilişkinin olmadığ durumda 0 , tam ve kuvvetli bir ilişki varsa 1 , ters yönlü ve tam bir ilişki varsa -1 değerini alır (Altunışık ve Diğerleri 2010). Korelasyon analiz sonuçlarına bakıldığında olgular arasındaki korelasyon değerlerinin yeterli olduğu görülmektedir. 
Tablo 3.2 Değişkenler Arasındaki Korelasyon Analiz Sonuçları Tablosu

\begin{tabular}{|c|c|c|c|c|}
\hline \multicolumn{5}{|c|}{ Korelasyonlar } \\
\hline & & İstenayriort & PayLidOrt & PsiGuvOrt \\
\hline \multirow[t]{3}{*}{ İstenayriort } & Pearson Correlation & 1 &,$- 799^{* *}$ &,$- 397^{* *}$ \\
\hline & Sig. (2-tailed) & &, 000 &, 000 \\
\hline & $\mathrm{N}$ & 326 & 326 & 326 \\
\hline \multirow[t]{3}{*}{ PayLidOrt } & Pearson Correlation &,$- 799^{* *}$ & 1 &, $495^{* *}$ \\
\hline & Sig. (2-tailed) &, 000 & &, 000 \\
\hline & $\bar{N}$ & 326 & 326 & 326 \\
\hline \multirow[t]{3}{*}{ PsiGuvOrt } & Pearson Correlation &,$- 397^{* * *}$ &, $495^{* *}$ & 1 \\
\hline & Sig. (2-tailed) &, 000 &, 000 & \\
\hline & $\mathrm{N}$ & 326 & 326 & 326 \\
\hline
\end{tabular}

\section{Bulgular ve Yorum}

WARPLS yapısal eşitlik modelleme analizi yapan programlar içinde doğrusal olmayan fonksiyonlar içindeki örtülü değiş̧kenleri açığa çıkararak kurulan ilişkide çoklu değişkenlerin katsayılarını hesaplandığı ve dağılımların normal olmadığı durumlarda dahi yüksek güvenirlikte sonuçlar veren bir programdır (Kock, 2013). Bununla beraber son versiyonu olan WarpPLS 4.0 versiyonu ise önceki uygulamalarından daha fazla olarak aracı değişken modelli algoritmaların analizini sunarken iki değişkenli (bivariate) analizler olan çapraz tablo yada korelasyon gibi yöntemlerde çıkması muhtemel Simpson paradoksu tehlikesini en aza indirmektedir (Mat Roni, 2015). Simpson Paradoksu iki değişkenli bir duruma göre karar verildikten sonra bir üçüncü değişkenin bu ilişkiyi etkilediği durumlarda çıkan çelişki olarak tanımlanabilir. Modelin sunmuş olduğu bazı oranlar araştırmacı ve değerlendirmeciler için kolaylık sağlamaktadır. Bu oranlar APC (Average Path Coefficiant,Ortalama İlişki Katsayısı), Ortalama Belirleme Katsayısı (ARS, determinasyon katsayısı, bağımsız değişkenin bağımlı değişkeni açıklama katsayısı), Ortalama Tam Doğrusallık (Average Full Collinearity VIF, AFVIF,(Örtük değişken göstergesi), GoF (Tenenhaus Goodness of Fitness, Modelin açıklama gücü,), SPR (Simpson's Paradox Ratio, Simpson Paradoksu Oranı), SSR (Statistical Suppression Ratio, Nedensellik Problemi Göstergesi), RSCR (Olumsuz R kare etkisi oranı), NLBCDR ( İki değişkenli doğrusal olmayan katsayıların ortalama $\mathrm{R}^{2}$ oranı ) modelde eğer örtük (latent) değişken varsa artacak bu ise APC (Average Path Coefficiant, Ortalama İlişki Katsayısı) oranını azaltacaktır (Realyvásquez vd., 2016).

AVIF (Ortalama Doğrudaşlık, Doğrusallık) indeksi modelde örtük değişken olduğu zaman artmaktadır. $\mathrm{Bu}$ indeks modele dikey doğrusallık katmaktadır. AFVIF indeksi ise modelin tam doğrusallık (Çoklu Doğrudaşlık, Multi Collinearity) oranını göstermektedir. Yüksek AVIF ve AFVIF oranları modelde yeni örtük değişkenlerin modeldeki örtük değişkenlerin anlamlarını bastırdığını göstermektedir (Williams, 2015). Bu ise araştırmanın halihazırdaki tahmin edici veya açıklayıcı gücüne yeni bir model sunmayı gerektirmektedir. Bu değerlerin 5 veya 5 'ten küçük olması bağımlı değişkeni açıklayan bir tane bağımsız değişken olduğunu göstererek araştırma modelinin uygun olduğunu teyit etmektedir. (Kock ve Lynn,2012). Analiz kapsamında modelde çoklu doğrusal bağlantı 
sorunu olup olmadığını belirlemek maksadıyla doğrudaşlığa (collinearity) bakılmaktadır. Elde edilen tolerans ve VIF değerleri bağımsız değişkenler arası çoklu bağlantı olmadığını doğrulayan sonuçlar vermiştir

Tenenhaus vd. (2005) GoF (Goodness of Fit) indeksini modelin açıklayıcı gücü olarak tanımlamaktadır. GoF değeri Ortalama Oransal Etken Değişkeni (Communality Idex) indeksi ve Ortalama $\mathrm{R}^{2}$ ilişkisinin karekökü olarak tanımlanmıştır. Araştırmada Orl Etken Değişken (Communality) İndeksi örtük değişkenlerin yüklemelerinin karelerinin (squared loadings) toplamı olarak hesaplanır. Ortalama Oransal Etken Değişken indeksinde ise bütün örtük değişkenlerin modele etkileri hesaplanır. Bu değer 0,5 ten büyükse modelin açılayıcı gücünün çok iyi, ve modelin uygun olduğunu göstermekle beraber 0.1 den küçükse kabul seviyesinin altında olduğunu göstermektedir. Yani 0.1 değerinden daha küçük bir GoF değerine sahip bir model araştırma için uygun değildir.

SPR indeksi ise araştırma modelinin Simpson paradoksundan ne kadar etkilendiğini göstermektedir (Pearl, 2013). Simpson Paradoksu araştırmada analize dahil edilmeyen değişkenlerin etkisi gibi olasılıkların da dikkate alınması gerektiğini belirten bir olgudur. Simpson paradoksu olarak adlandırılan durum nedeniyle, bir çift değişken arasındaki ilişki yok olabileceği gibi yön değiştirebilir. Simpson paradoksu örneklem büyüklüklerinin birbirlerinden çok farklı olmasından kaynaklanıyor olabilir. Simpson paradoksu ile karşılaşmamak için tabakalı örneklemenin dikkatli yapılması ve mümkün olduğu kadar aynı büyüklüklerde tabakaların alınması gerekmektedir. Araştırmada modelin uygun görülmesi için SPR indeksinin 0,7 den büyük olması gerekmektedir. En uygun değeri ise 1'dir (Kock,2013)

Kock (2013) RSCR (R Squared Contributions Ratio,) Modelin Simpson Paradoksunun etkisinde kaldığı durumlarda bağımsız değişkenin bağımlı değişkendeki oranı düşürdüğü durumlarda ortaya çıkmaktadır. Araştırmada örtük bağımsız değişken diğer örtük değişkenin $\mathrm{R}^{2}$ oranına olumsuz etki yaptığında RSCR indeksi araştırma modelinin uygun olmadığını göstermektedir. RSCR indeksi SPR (Simpson Paradoksu Oranı) indeksine benzemekle beraber RSCR indeksi bir modeldeki olumlu $\mathrm{R}^{2}$ etkisine sahip ilişkilerin modeldeki tüm ilişkilerdeki $\mathrm{R}^{2}$ etki toplamına bölünmesiyle ortaya çıkar. Uygun olan RSCR orası ise 1'dir (Gupta vd., 2015). Bunun anlamı ise modelde hiçbir negatif $\mathrm{R}^{2}$ (olumsuz determinasyon, belirleme katsayısı) etkisine sahip ilişkinin olmadığını göstermektedir. Araştırmalar için ortalama kabul oranı ise 0.9 olup buda araştırma modelindeki ilişkilerin yüzde doksanının olumlu etkisini göstermektedir.

Psikolojik rahatlık algısının, paylaşılan liderlik davranışı ve işten ayrılma niyeti arasındaki ilişkide aracılık rolünü belirlemek için Baron ve Kenny (1986) tarafindan önerilen üç aşamalı regresyon analizi yapılmıştır. Bunun için öncelikle bağımsız değişken (Paylaşılan Liderlik) ile bağımlı değişken (İşten Ayrılma Niyeti) arasında bir sebep sonuç ilişkisinin var olması gerekmektedir (Şekil 4.1). Daha sonra yine bağımsız değişkenin aracılık etkisine sahip olduğu düşünülen değişkeni (psikolojik rahatlığı) anlamlı bir şekilde etkiliyor olması gerekmektedir. Son olarak da, bağımsız değişken kontrol altında tutulurken, aracı değişkenin bağımlı değişkeni anlamlı bir şekilde etkilemesi gerekmektedir (Şekil 4.2). Bu analizler sonucunda bir aracılık etkisinden bahsedebilmek için bağımsız değişkenin bağımlı değişken üzerindeki etkisine bakılmaktadır. Bu etkinin azalması durumunda "kısmi aracıllk", etkinin tamamen ortadan kalkması durumunda ise "tam aracılık" etkisinden söz edilebilir. Ancak aracı değişkenin bu arada, bağımlı değişken ile arasındaki ilişkinin anlamlılık düzeyini koruması da gerekmektedir (Baron ve Kenny, 1986). 


\subsection{Paylaşılan Liderlik Davranışı ve İşten Ayrılma Niyeti Arasındaki İlişki}

Şekil 4.1. Paylaşılan Liderliğin İşten Ayrılma Niyetine Olan Etkisi

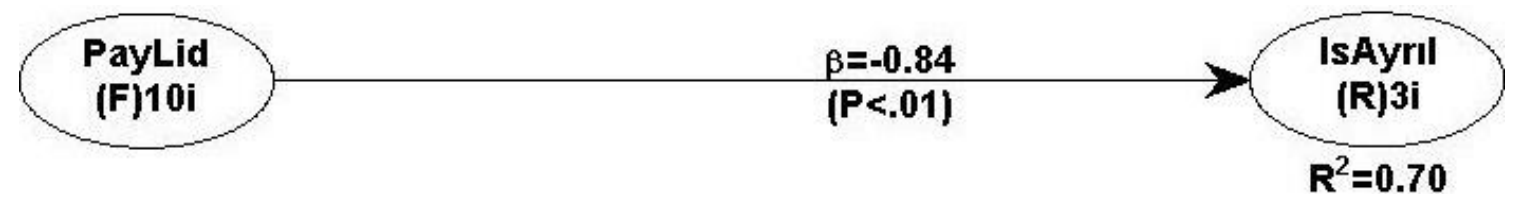

Paylaşılan Liderlik davranışının işten ayrılma niyeti üzerindeki etkisine yönelik yapılan WARPPLS uygulamasından alınan regresyon analizi sonuçları yukarıda olup veriler aşağıda sıralanmıştır.

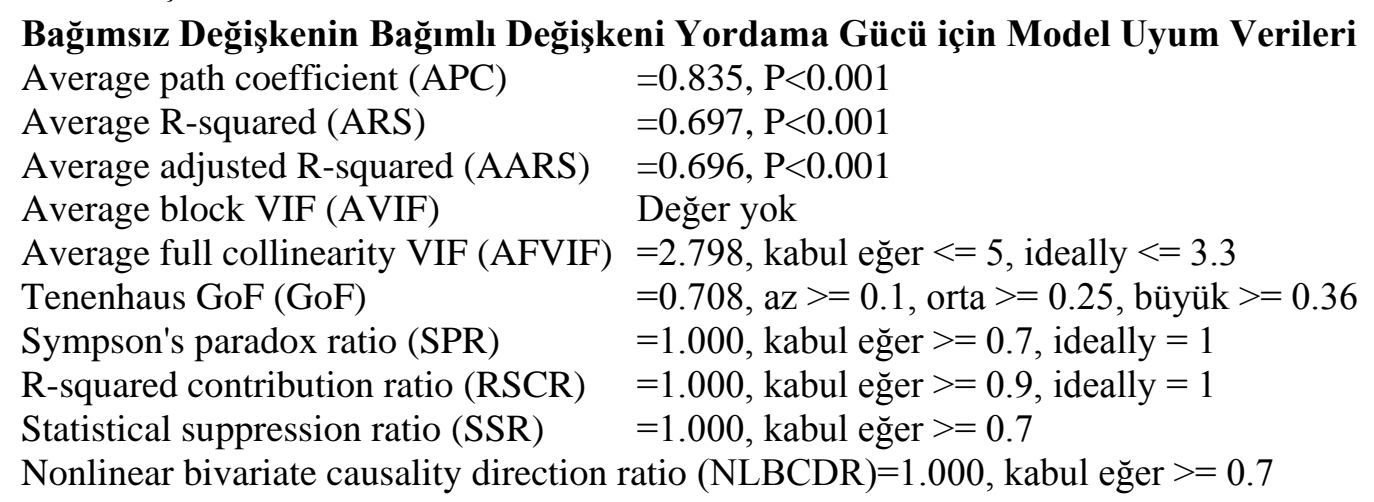

Araştırmada kullanılan kısmi en küçük kareler yönteminin sonuçlarına bakıldığında yöneticilerin göstermiş olduğu paylaşılan liderlik davranışlarının işten ayrılma davranışına etkisine ilişkin analizi anlamlı ve olumsuzdur. Yöneticilerin paylaşılan liderlik davranışının işten ayrılma davranışına etkisi -0.84 olup buda gösterilen olumlu paylaşılan liderlik davranışının işten ayrılma niyetini \% 84 daha azalttığını bize göstermektedir . İşten Ayrılma Niyetinin \% 70'inin paylaşılan liderlik davranışıyla açıklanabildiği $\mathrm{R}^{2}=0,70$ (determinasyon katsayısı) değeriyle analiz sonucunda görülmektedir. ( $\mathrm{R}^{2}=0,70, \beta=-0,84$ ve $\mathrm{p}<0.01$ ). Bulgulara göre paylaşılan liderlik davranışının işten ayrılma niyetini olumsuz ve anlamlı bir şekilde etkilediği dolayısıyla $\mathrm{H}_{1}$ hipotezinin doğrulandığ1 söylenebilir. Baron ve Kenny (1986) aracı değişken etkinin oluşması için gerekli şartlardan ilki olan bağımsız değişken ve bağımlı değişken arasında anlamı bir ilişkinin olması şartının da sağlandığı görülmektedir.

\subsection{Paylaşılan Liderlik Davranışı ve Psikolojik Rahatlık Algııı Arasındaki İliş̧kiye Yönelik Bulgular ve Yorum}

Araştırmanın bu aşamasından itibaren yapılan regresyon analizine değişkenlerin tamamı dahil edilmiştir. Dolayısıyla diğer üç hipotez aşağıdaki sonuçlara göre yorumlanacaktır. 


\section{Şekil 4.2 Tam Araştırma Modeli ve Aracılık Analizi}

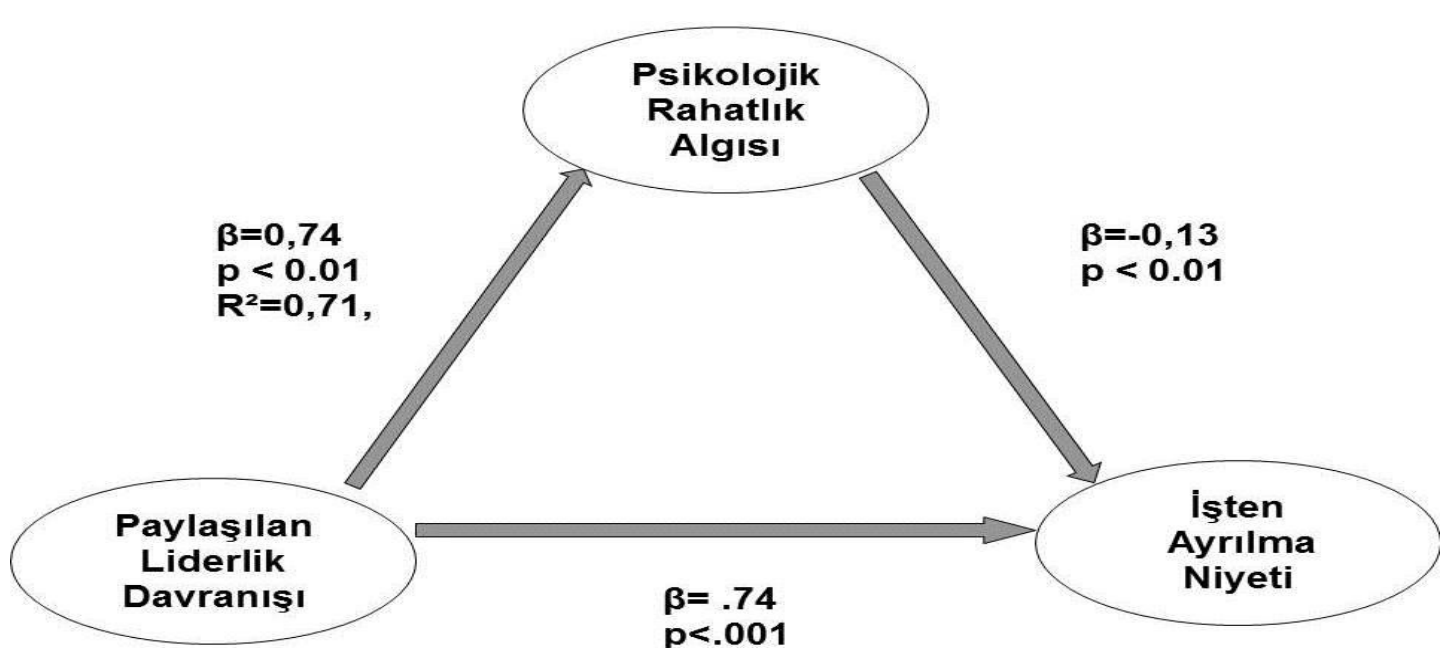

Tam Araştırma Modeli ve Aracılık Analizi için Model Uyum Değerleri

$\begin{array}{ll}\text { Average path coefficient (APC) } & =0.538, \mathrm{P}<0.001 \\ \text { Average R-squared (ARS) } & =0.628, \mathrm{P}<0.001 \\ \text { Average adjusted R-squared (AARS) } & =0.627, \mathrm{P}<0.001 \\ \text { Average block VIF (AVIF) } & =1.971, \mathrm{kabul} \text { eğer }<=5, \text { ideal }<=3.3 \\ \text { Average full collinearity VIF (AFVIF) } & =2.915, \mathrm{kabul} \text { eğer }<=5, \text { ideal }<=3.3 \\ \text { Tenenhaus GoF }(\mathrm{GoF}) & =0.623, \text { az }>=0.1, \text { orta }>=0.25, \text { büyük }>=0.36 \\ \text { Sympson's paradox ratio (SPR) } & =1.000, \text { kabul eğer }>=0.7, \text { ideal }=1 \\ \text { R-squared contribution ratio (RSCR) } & =1.000, \text { kabul eğer }>=0.9, \text { ideal }=1 \\ \text { Statistical suppression ratio (SSR) } & =1.000, \text { kabul eğer }>=0.7 \\ \text { Nonlinear bivariate causality direction ratio }(\mathrm{NLBCDR})=1.000, \text { kabul eğer }>=0.7\end{array}$

İkinci hipotez olan 'Yöneticilerin paylaşılan liderlik davranışı çalışanların psikolojik rahatlık algısını olumlu yönde etkilemektedir' hipotezin doğrulanması için uygulanan kısmi en küçük kareler yönteminin sonuçlarına bakıldığında yöneticilerin göstermiş olduğu olumlu paylaşılan liderlik davranışlarının psikolojik rahatlık algısına etkisi anlamlı ve olumludur. Yöneticilerin olumlu paylaşılan liderlik davranışı psikolojik rahatlık algısına olan etkisi 0.74 olup buda gösterilen olumlu paylaşılan liderlik davranışının psikolojik rahatlık algısını \% 74 daha arttırdığını bize göstermektedir. Psikolojik rahatlık algısının \% 71'inin paylaşılan liderlik davranışılla açıklanabildiği $\mathrm{R}^{2}=0,71$ (determinasyon katsayısı) değeriyle analiz sonucunda görülmektedir $\left(\mathrm{R}^{2}=0,71, \beta=0,74\right.$ ve $\left.p<0.01\right)$.

\subsection{Psikolojik Rahatlık Algısının İşten Ayrılma Niyetiyle arasındaki iliş̧iye Yönelik Bulgular ve Yorum}

Kısmi en küçük kareler yönteminin sonuçlarına bakıldığında çalışma ortamında algılanan olumlu psikolojik rahatlık algısının işten ayrılma davranışına etkisi olumsuz ve anlamlıdır. Çalışanların olumlu psikolojik rahatık algısının işten ayrılma eğilimine etkisi -0.13 olup bu sonuç algılanan olumlu psikolojik rahatlık algısının işten ayrılma davranışını \% 13 daha azalttığını bize göstermektedir. Bu sonuç ta bu hipotezimizi doğrulamaktadır ( $\beta=-0,13$ ve $\mathrm{P}<0.01)$. 


\subsection{Psikolojik Rahatlık Algısının Aracı Değişken Rolüne İlişsin Bulgular ve Yorum}

Aracılık testi amacıyla ilk olarak paylaşılan liderlik, psikolojik rahatlık algısı ve işten ayrılma niyeti arasındaki ilişkilere bakılmıştır. Elde edilen bulgular yukarıdaki şekil ve şeklin altındaki verilerde görülmektedir. $\mathrm{Bu}$ aşamada paylaşılan liderlik davranışının bağımlı değişken olan işten ayrılma niyetini $(\beta=-0,84, \quad \mathrm{p}<.001)$ anlamlı ve olumsuz yönde etkilediği görülmüştür. Daha sonra paylaşılan liderliğin , aracı değişken olarak kabul edilen psikolojik rahatlık algısı ile olan ilişkisi incelenmiştir. Analiz sonucunda paylaşılan liderlik davranışının aracı değişken olarak kabul edilen psikolojik rahatlık algısını $(\beta=.74 ; p<.001)$ anlamlı ve olumlu yönde etkilediği tespit edilmiştir. Son olarak paylaşılan liderlik davranışı ile psikolojik rahatlık algısı birlikte analize dahil edilmiş ve ikisinin işten ayrılma niyeti üzerindeki etkisi araştırılmıştır. Bu aşamada paylaşılan liderlik davranışının işten ayrılma niyeti üzerindeki etkisi devam etmiş ancak analize psikolojik rahatlık algısının girmesiyle birlikte azalmıştır. $(\beta=-.74 ; p<.001$, aracı değişkenden önce $\beta=-0,84, \quad \mathrm{p}<.001)$. Bu bulgular doğrultusunda psikolojik rahatlık algısının paylaşılan liderlik davranışının işten ayrılma niyeti üzerindeki etkisini azaltması fakat anlamlılı̆̆ını yitirmemesinden dolayı, bu ilişkide psikolojik rahatlık algısının kısmi aracılık rolünden bahsetmek mümkündür.

\section{TARTIŞMA VE SONUÇ}

Psikolojik rahatlık algısının değinildiği ilk çalışmaların geçmişi eski olsa da (Schein ve Bennis, 1965) ulusal ve uluslararası alanyazında kayda değer çalışmalara konu olması çok eski değildir. Psikolojik rahatlık algısının doğrudan yada dolaylı iş hayatına, mikro ve makro ekonomik hayata, sosyolojik hayata, aile hayatına ciddi etkileri olduğu aşikar olup gün geçtikçe daha çok araştırmaya konu olmaktadır. Sadece İngiltere'de stres ve zayıf psikolojik rahatlık algısı kaynaklı işgören devrinin ekonomiye yıllık maliyetinin 25.9 milyar pound olduğu tahmin edilmektedir. (Dollard ve diğerleri,2012:2).

Araştırma sonuçlarını destekleyen bir çalışmada Dollard vd. (2012:2) 23 Polis Merkezinde 14 ay süren araştırmasında çalışma ortamında çalışandan yüksek iş beklentisinin olduğu ortamlarda organizasyonda olumlu psikolojik rahatlık algısının iş stresine olan etkisi araştırılmıştır. Araştırmacılar olumlu psikolojik rahatlık algısının yerleşmiş olduğu organizasyonlarda yüksek iş yüküne rağmen hissedilen iş stresinin psikolojik rahatlık algısının yerleşmemiş olduğu organizasyonlara nazaran daha düşük olduğunu gözlemlemişlerdir (Dollard ve diğerleri, 2012:5). Aynı araştırmanın içinde iş alanlarındaki psikolojik tehlikeler sebebiyle oluşan psikolojik rahatsızlıkların işgörenin sağlığını ciddi olarak etkilediği ve iş gören maliyetini arttırdığ 1 belirtilmektedir.

Schepers ve diğerlerinin (2007:9) 361 üniversite öğrencisiyle yaptıkları çalışmada psikolojik rahatlık algısının çalışma takımlarında kişilerarası güven ve değer görme algısını güçlendirdiği ve eğitim ortamlarında teknoloji kullanımını teşvik ettiği gözlemlenmiştir. Çalışma takım teknolojileriyle oluşturulmuş çalışma organizasyonlarında yapılmış olup takım teknolojileriyle kastedilen olgu kişilerarasında eşgüdüm, işbirliği, iletişimi sağlamak üzere elektronik ağların kullanıldığ 1 çalışma organizasyonlarıdır. $\mathrm{Bu}$ sayede geri besleme, fikir alışverişi, tartışma forumları, bilgi değişimi, mesajlaşma sağlandığ için organizasyon üyelerinin coğrafi ve zamansal engellerin üstesinden gelmesi sağlanmaktadır. Olumlu psikolojik rahatlık algısının olduğu organizasyonlarda bu tür grup teknolojilerinin kullanımının daha yaygın olduğu bu araştırma sonuçlarına göre iddia edilmektedir. Grup teknolojilerinin oluşum sürecinde kişilerarası güvenin anahtar rolünde olduğu iddia edilmektedir (Schepers ve diğerleri, 2007:5).

Walumbwa ve Schaubroeck (2009:10)'1n ABD'de büyük finans kuruluşlarında çalışan 894 çalışan ve 222 yönetici üzerinde yaptıkları 'Liderlik özellikleri ve çalışanın ifade özgürlügünde etik liderlik ve psikolojik rahatlık algısının aracı değişken rolü” adlı araştırmasında liderlerin etik 
davranışlarının çalışanların kendilerini ifade seviyesini artırdığını ve rahatlık algısının bu ilişkide kısmi aracı değişken rolü üstlendiği gözlemlenmiştir.

Nergiz (2014)'in Kocaeli'de bulunan otellerde yapmış olduğu ve psikolojik rahatlık algısını sonuç davranışı olarak incelemiş olduğu çalışmasında hata yönetimi davranışı ile psikolojik rahatlık algısını arasında olumsuz ve anlamlı bir ilişki saptamıştır. Alanyazında yapılan diğer çalışmalara göre farklı bir model ve sonuç ortaya koyan çalışmada çalışanların olumsuz hata yönetimi sergilediklerinde çalıştıkları kurumda kişilerarası psikolojik endişelerinin arttığ ifade edilmektedir. Araştırmanın önemi hem ulusal hemde uluslararası alanyazında psikolojik rahatlık algısının sonuç olarak inceleyen nadir araştırmalardan olması ve psikolojik rahatlık algısının belirleyicilerinden bir tanesini ortaya koymasidir.

Ulusal alanyazında yapılan bir başka güncel çalışmada Alkan ve Turgut (2015) psikolojik rahatlık algısının zorunlu örgütsel vatandaşlık ve örgütsel siyaset üzerindeki etkisini incelemişlerdir. Finans kurumlarında yoğun ve baskı altında çalışan personel üzerinde yapılan çalışmada psikolojik rahatlık algısının zorunlu örgütsel vatandaşlık olgusu üzerinde olumsuz ve anlamlı bir ilişkisi tespit edilmiştir. Bu iki olgu arasındaki ilişkiye örgütsel siyaset algısı dahil edildiğinde bu etki ortadan kaybolarak örgütsel siyaset algısının psikolojik rahatlık algısı üzerindeki baskısı ortaya çıkmıştır. Çalışmanın psikolojik rahatık algısının etkisinin en fazla görüleceği sektörlerden bir tanesi olan finans sektöründe yapılması boyutlarının daha net ortaya koyulmasına katkı sağlamıştır. Bununla beraber bahsedilen her iki ulusal çalışma da psikolojik rahatlık algısının ülkemizde ele alındığını göstermektedir. Araştırmalarda çıkan sonuçlar ise daha fazla araştırmaya ihtiyaç olduğunu göstermektedir.

Pozitif psikoloji gibi işletme alanyazına yeni giren bir olgunun bir boyutu olan psikolojik rahatlık algısının işletmelerde sonuca yönelik verimlilik, etkinlik ve performansı arttırdığını, örgütsel bağlılık oluşturduğunu ortaya koyan çalışmalar giderek artmaktadır. Psikolojik rahatlık algısının alanyazına ilk girdiği çalışmada örgütsel öğrenme ve bilgi paylaşımına yönelik etkisi sorgulanmıştır (Edmondson, 1999). Eğitim kurumlarının en önemli araçlarından olan bilgi paylaşımı olgusunun işletmelerde de aynı amaçlarla kullanılmasının rekabet güçlerini olumlu etkileyebileceği düşünülmektedir. Bundan sonraki çalışmalar da psikolojik rahatlık algısının çeşitli kuramlar tabanında rekabet unsurlarını nasıl etkilediğini ortaya koyan çalışmalar yapılarak konunun boyutları arttırılabilir. 
ABASSİ, S. M. ve Hollman, K. W. (2000). Turnover: The real bottom line. Public Personnel Management, Vol. 2 No. 3, 333-342.

ALKAN, S.E. ve Turgut, T. (2015). A Research about the relationship of psychological safety and organisational politics perception with compulsory citizenship behavior and the pressures behind compulsory citizenship behavior. Research journal of Business and Management, 2015, 2(2), 185 203.

ALTUNIŞIK, R., Coşkun, R., Bayraktaroğlu, S. ve Yıldırım, E.(2010). Sosyal Bilimlerde Araştırma Yöntemleri, Sakarya, Sakarya Kitabevi.

BALTAŞ,A. ve Baltaş Z. (1987). Stres ve Başa Çıkma Yolları,Remzi Kitabevi,İstanbul, 1987.

BARON, R. M. ve Kenny, D. A.(1986). The Moderator- Mediator Variable Distinction in Social Psychological Research: Conceptual,Strategic and Statistical Considerations. Journal of Personality and Social Psychology.1986,51,6.1173-1182

BAUER, T., Erdogan, B., Liden, R., ve Wayne, S. (2006). A longitudinal study of the moderating role of extraversion: Leader-member exchange, performance, and turnover during new executive development. Journal of Applied Psychology, 91, 298-310.

BECKER, G. (1964). Human Capital, 2nd edn. Columbia University Press, New York, 1994

BECKER, G. (1993). The economic way of looking at behavior. J Polit Econ 101(3):385-409

BOLDEN, R. (2011). Distributed Leadership in Organizations: A Review of Theory and Research. International Journal of Management Reviews, 13(3), 251-269.

BOOTZIN, R. ve Loftus,E. (1983). Robert Psychology, Today in Introduction. Random House, New York, 1983.

BOTHMA, C. F. C. ve Roodt G. (2012). The Validation of the Turnover Intention Scale, Journal of Human Resource Management, 11,1,2013.

COLDWELL, S. (2012). Addressing Workplace Bullying and Harassment in Canada, Research,Legislation and Stakeholder Overview.

DAFT, R. L. (2005). The leadership experience. Mason, OH: Thomson, South-Western.

DELUGA, R. J. (1994). Supervisor trust building, leader-member exchange and organizational citizenship behaviour. Journal of Occupational and Organizational Psychology, 1994, 67, 315-326

DOLLARD, M., Tuckey, M. R. ve Dormann, C. (2012). Psychological Safety Climate Moderates the Job Demand-Resource Interaction in Predicting Workgroup Distress, Accident Analysis and Prevention 45,2012, 694-704.

DRAPER, M. R., Jennings, J. ve Baron, A. (2003). Factor Analysis and Concurrent Validity of a University Counselling Center Presenting Problems Checklist, 2003.

DUNEGAN, K., Uhl-Bien, M. ve Duchon, D. LMX and subordinate performance: the moderating effects of task characteristics, Journal of Business and Psychology, 2002,17,275-285, 2002.

EDMONDSON, A. C.(1999). Psychological Safety and Learning Behavior in Work Teams, Administrative Science Quarterly,Jun 1999,44,2. 350-384.

EDMONSON, A. C.(2003). Psychological Safety,Trust and Learning in Organizations, AGroup Level Lens, Erişim Tarihi 20 Şubat 2014, Sciencedirect Veritabanı.

EGGERS, J. T. (2010). Psychological Safety Influences Relationship Behaviour. Erişim Tarihi 20 Şubat 2014, Sciencedirect veritabanı. 
EROĞLU, E. (2003).Toplam Kalite Uygulamalarının Yapısal Eşitlik Modeli ile Analizi, İstanbul Üniversitesi Sosyal Bilimler Enstitüsü İşletme Bölümü, Yayınlanmamış Doktora Tezi.

EREN, E. (1998). Örgütsel Davranış ve Yönetim Psikolojisi. Beta Basım ve Yayınevi.1998. S.224.

EXODUS

$(18,21,22)$.

https://www.biblegateway.com/passage/?search=Exodus+18\%3A21-22

FIEDLER, F. E. (1967). A theory of leadership effectiveness. New York: McGraw-Hill, 1967

GUPTA, G., Zaidi, S., Udo, U. ve Bagchi, K. (2015). The Influence of Theory of Planned Behavior, Technology Acceptance Model, and Information System Success Model on the Acceptance of Electronic Tax Filing System in an Emerging Economy. The International Journal of Digital Accounting Research, 15, 2015, 155-185.

HIRSCHMAN, A. O. (1970). Exit, Voice, and Loyalty: Responses to Decline in Firms, Organizations, and States. Cambridge, MA: Harvard University Press. ISBN 0-674-27660-4 (paper).

KOCK, N. (2013). WarpPLS 4.0 User Manual. Laredo, TX: ScriptWarp Systems.

KOCK, N., ve Lynn, G.S. (2012). Lateral Collinearity and Misleading Results in Variancebased SEM: An illustration and Recommendations. Journal of the Association for Information Systems (13:7),546-580.

MAT RONI, M. S. (2015). An analysis of insider dysfunctional behavours in an accounting information system environment. Unpublished Doctoral Thesis, Edith Cowan University, 2016.

NCSL, (2004a). Learning-centred Leadership (Pack 1), Nottingham, NCSL, 2004

NCSL, (2004b).Meeting the Challenge: Growing Tomorrow's School Leaders - a practical guide for school leaders, Nottingham, NCSL, 2004

NERGIZ, H. G. (2014). Otel işletmelerinde hata yönetiminin psikolojik güvenlik, örgütsel performans ve örgütsel öğrenme üzerindeki etkisi. Anatolia, Turizm Araştırmaları Dergisi, 26(2), 221-237.

PEREZ, M. (2008). Turnover Intent. Zurich University, Human Resources Management. Unpublished Diploma Thesis.,2008

ÖZER, N. ve Beycioğlu, K. (2013). Paylaşılan liderlik ölçeğinin geliştirilmesi: geçerlik ve güvenirlik çalışmaları. İlköğretim Online, 12(1), 77-86.

ÖZÇELIKK, D.A. (1981). Okullarda ölçme ve değerlendirme. Ankara: ÜSYM-Eğitim Yayınlar1; 1981.

PEARL, J. (2013). Understanding Simpson's Paradox. The American Statiscian, 2014, Technical Report.

PODSAKOFF, N. P., LePine, J. A., ve LePine, M. A. (2007). Differential challenge stressorhindrance stressor relationships with job attitudes, turnover intentions, turnover, and withdrawal behavior: a meta-analysis. Journal of Applied Psychology, 92(2), 438.

RAMSAY, C. S., ve Finney, M. I. (2006). Employee engagement at Intuit. Mountain View, CA: Intuit Inc.

REALYVÁSQUEZ, A. Maldonado-Macías, A. A. García-Alcaraz, J. Cortés-Robles, G. ve Blanco-Fernández, J. (2016). Structural Model for the Effects of Environmental Elements on the Psychological Characteristics and Performance of the Employees of Manufacturing Systems. Int. J. Environ. Res. Public Health 2016, 13(1), 104. Reily, D. (2006). Turnover intention. The mediation effect of job satisfaction, affective commitment and continuance commitment. Master thesis, University of Waikato. 
SAMRA, J., Gilbert, M., Shain, M. and Bilsker, D. (2012). What is Psychological Health and Safety. Centre for Applied Research in Mental and Addiction (CARMHA) Handout.(2014).

SCHEIN, E., ve Bennis, W. (1965). Personal and Organizational Change through Group Methods. New York: Wiley.

SCHEPERS, J., Jong, A.,Wetzels, M. ve Ruyter, K. (2007). Psychological Safety and Social Support in Gropuware Adoption. A Multi-level Assessment in education. Computers and Education 51(2008).757-775.

SERRAT, O. (2009). Distributing Leadership. Cornell University International Publications, 10, 2009.

SPİLLANE, P.J. Halverson,R.,Diamond, John (2004). Towards a Theory of Leadership Practice; A Distributed Perspective. Journal of Curriculum Studies. 1, 3-34.

TENENHAUS, M., Esposito Vinzi, V., Chatelin, Y., and Lauro, C. (2005). PLS path modeling.

Computational Statistics and Data Analysis, 48, 159-205.

THELEN, K. (2003). How Institutionalism Evolves: Insights from Comparative Historical Analysis. 2003, 208-240.

ŞENYÜZ, P. B. (2003). Örgütsel Bağlılığa Etki Eden Faktörler ve Örgütsel Bağlılık İle İşten Ayrılma Eğilimi İlişkisi Üzerine Bir Araştırma. Gebze Yüksek Teknoloji Enst. Doktora Tezi.

WALUMBWA, F. O. and Schaubroeck, J. (2009). Leader Personality Traits and Employee Voice Behavior : Mediating Roles of Ethical Leadership and Work Group Psychological Safety. Journal of Applied Psychology, 2009,94-5 1275-1286.

WILLIAMS, R. (2015). Multicollinearity. University of Notre Dame, http://www3.nd.edu/ rwilliam/, https://www3.nd.edu/ rwilliam/stats2/111.pdf, Erişim tarihi 07 Ekim 2016.

YENER, S. (2015a). Paylaşılan Liderlik Davranışının İşten Ayrılmaya Etkisinde Psikolojik Güvenlik Algısının Aracı Değişken Rolü. Haliç Üniversitesi Yayınlanmamış Doktora Tezi.

YENER, S. (2015b). Psikolojik Rahatlık Algısı Türkçe Formunun Geçerlik ve Güvenirlik Çalışması, ODÜ Sosyal Araştırmalar Dergisi, 1, 280-305. 